\title{
Brand Anthropomorphism and Culture Effect to Younger Consumer Visit Intention
}

\author{
Diesyana Ajeng Pramesti ${ }^{1}$, Marlina Kurnia ${ }^{2}$, Mulato Santosa ${ }^{3}$ \\ \{diesyana.ajeng@ummgl.ac.id ${ }^{1}$ \} \\ Management Department, University of Muhammadiyah Magelang, Magelang, Indonesia ${ }^{1,2,3}$
}

\begin{abstract}
RedDoorz has become one of the brands that is easily found in every city in Indonesia past 5 years. In that time, many investors have collaborated with RedDoorz because there are cultural shift, especially young people who like to vacation during their holidays. This study aims to examine whether the brand anthropomorphism and culture about holiday affect their intention in visiting hotels labeled RedDoorz. The survey was conducted in Yogyakartaand Central Java using questionnaires to 92 young people who became respondents. The collected data were processed using SPSS 2.5 with moderation regression analysis techniques. The results obtained by Brand Anthropomorphism have a positive and significant effect on visiting intentions and culture moderates the influence of Brand Anthropomorphism on visit intentions, so it can be concluded that culture greatly influences psychology and the way of thinking of humans, especially young people in making a decision to visit RedDoorz.
\end{abstract}

Keywords: Brand Anthropomorphism, Culture Effect, Visit Intention, Younger Consumer

\section{Introduction}

"RedDoorz" is a popular hotel management and booking platform that has been accessed by more than 100 cities in Indonesia and other ASEAN countries. As the fastest growing hotel chain in Southeast Asia, "RedDoorz" strives to support the convenience and ease of customer access at an affordable cost [1]. Datas about booking growth on "RedDooorz" from 2017 to 2019 has increased on average 6 times every year. The Asia Travel Leaders' Summit said that in Indonesian, younger tourists were $23.95 \%$ of the total tourists, the majority chose "RedDoorz" as their place to stay [2], because the youngers really paid attention to affordability and preferred an easy and fast system for ordering hotels using digital platforms. This is what makes "RedDoorz" to be the most popular platform today and is predicted to become a unicorn start-up by the end of 2020 [3]. "RedDoorz" uses the anthropomorphism brand strategy in approaching its target market. [4] said that the concept is suitable for use in marketing a hotel. This strategy is very effective in communicating the brand. Brand anthropomorphism has a very significant effect on marketing [5]. Brands anthropomorphism become agents that are easy, practical, and communicative [6]. [7] [8] said that the company's attachment to consumers is due to frequent interactions between the two, both emotionally, psychologically, and physically. This closely is influenced by external factors such as references and advertisements [9]. Local wisdom has a significant influence on choosing "RedDoorz" brand. With a strong relationship, it creates an intention to use that brand. 
In anthromormphism theory, humans assume that objects (objects) seem to have humanlike characteristics and personalities [10], one of this is social relations [11]. If belief is strong, then anthropomorphism is weak, and vice versa if belief is weak, then anthropomorphism is strong. According to [12] the market positioning strategy needed to get consumers. With the brand anthropomorphism, it is easier to influence the target market. Research on brand anthropomorphism has been conducted by [13] Brand anthropomorphism: Conceptualization, measurement, and impact on brand personality and loyalty which discusses the impact of hotel brand anthropomorphism on customer visit intentions. This was also done by [14] who used anthropomorphism as an effective brand communication strategy for customers. Local brands position themselves as something unique and authentic because they connect local culture and heritage, national identity, and local market needs [15]. Based on this research, there are 2 (two) research objectives to be achieved, 1) whether brand anthropomorphism affects to the visit intention and 2) does the culture effect moderate the relationship between brand anthropomorphism and visit intention. In the research done before, researcher found that culture is the important factors that influenced people in order choosing brand. The other sides, there were limitation of literature about the relationship between brand anthropomorphism, culture, and visit intention.

\section{Method}

This research uses quantitative methods. The data collection technique used a survey by distributing questionnaires with measures by Likerts scale 1-5 (totally disagree - totally agree). The sampling technique was purposive sample with a sample of the younger consumers their age was 16-35 years who had stayed at a hotel in collaboration with the RedDoorz system. The number of samples in this study were 92 respondents. The data analysis method used is Moderated Regression Analysis to examine the moderating effect of the culture effect on the relationship between brand anthropomorphism and visit intention. The steps of statistical processes, first are validity analysis all of variables that are brand anthropomorphism as independent variable, visit intention as dependent variable, and culture effect as moderator variable using Confirmatory Factor Analysis and reliability analysis using Reliability Test, then $\mathrm{r}$-square test, and the last is T- test using moderating regression analysis.

\section{Results and Discussion}

\subsection{Statistic descriptive respondent}

In this study, there were 92 questionnaires that met the criteria of the 106 questionnaires that were distributed. The respondent data are as follows (Table 1). Then, statistic descriptive answering statement is presented in Table 2. From Table 2, the respondents' answers varied from totally disagree until totally agree, but that mean score is agree (Likert scale score 4). All the data obtained were then tested for validity using factor analysis and reliability testing to ensure that the data was truly valid and reliable. Overall data results are valid and reliable as follows (Table 3). 
Table 1. Students' Portfolio Scores of Oral Performance

\begin{tabular}{|c|c|c|c|}
\hline Criteria & & Total & Percentage \\
\hline \multirow[t]{3}{*}{ Gender } & a. Male & 23 & $75 \%$ \\
\hline & b. Female & 69 & $25 \%$ \\
\hline & Amount & 92 & $100 \%$ \\
\hline \multirow[t]{3}{*}{ Age } & a. $16-25$ years old & 79 & $85 \%$ \\
\hline & b. 26-35 years old & 13 & $15 \%$ \\
\hline & Amount & 92 & $100 \%$ \\
\hline \multirow[t]{3}{*}{ Education } & a. High school & 65 & $70,6 \%$ \\
\hline & b. Under graduate student & 27 & $29,3 \%$ \\
\hline & Amount & 92 & $100 \%$ \\
\hline \multirow[t]{7}{*}{ Profession } & a. $\quad$ Student & 2 & $0,2 \%$ \\
\hline & b. Under graduate student & 65 & $70,6 \%$ \\
\hline & c. Business & 7 & $0,7 \%$ \\
\hline & d. Professional & 7 & $0,7 \%$ \\
\hline & e. Teknicision & 0 & $0,0 \%$ \\
\hline & f. Others & 11 & $27,8 \%$ \\
\hline & Amount & 92 & $100 \%$ \\
\hline \multirow[t]{6}{*}{ Last Purchase Time } & a. Todays & 1 & $0,1 \%$ \\
\hline & b. Yesterday & - & $0 \%$ \\
\hline & c. Last week & 3 & $0,2 \%$ \\
\hline & d. Last month & 39 & $42,3 \%$ \\
\hline & e. Others & 49 & $57,4 \%$ \\
\hline & Amount & 92 & $100 \%$ \\
\hline
\end{tabular}

Table 2. Statistic descriptive answering statement

\begin{tabular}{lcccc}
\hline \multicolumn{1}{c}{ Variable } & Minimum & Maximum & Mean & Deviation Standard \\
\hline Brand antrophomorpism & 1.13 & 5.00 & 3.56 & 0.53 \\
Visit intention & 1.00 & 5.00 & 3.18 & 0.67 \\
Culture effect & 1.00 & 5.00 & 3.22 & 0.70 \\
\hline
\end{tabular}

Source: statistical data (2020)

Table 3. Validity and Reliability Analysis

\begin{tabular}{ccccc}
\hline \multicolumn{1}{c}{ Variable } & $\begin{array}{c}\text { KMO Battlet } \\
\text { test }\end{array}$ & Significance & $\begin{array}{c}\text { Cronbach } \\
\text { Alpha }\end{array}$ & Conclusion \\
\hline Brand antrophomorpism & 0.87 & 0.00 & 0.80 & valid and reliable \\
Visit intention & 0.56 & 0.00 & 0.72 & valid and reliable \\
Culture effect & 0.60 & 0.00 & 0.69 & valid and reliable \\
\hline
\end{tabular}

Source: statistical data (2020)

Furthermore, the test is conducted to determine the r-square value, and hypothesis testing using Moderating Regression Analysis with the results as follows (Table 4 and 5).

Table 4. Validity and reliability analysis

\begin{tabular}{llllll}
\hline & & \multicolumn{1}{c}{ Model } & B & T & sig. \\
& & (Constant) & 0.336 & 0.969 & 0.335 \\
1 & Visit Intention & Brand Antrophomorpism (X) & 0.798 & 8.288 & 0.000 \\
& (Y) & (Constant) & 0.710 & 0.799 & 0.426 \\
& & Brand Antrophomorpism (X) & 0.499 & 1.928 & 0.057 \\
2 & Visit & Culture Effect (Z) & 0.016 & 0.059 & 0.953 \\
& Intention (Y) & BA x AA (Moderasi) & 0.053 & 0.699 & 0.486 \\
\end{tabular}




\begin{tabular}{|c|c|c|c|c|c|}
\hline \multirow{3}{*}{$\begin{array}{l}1 \\
2\end{array}$} & & Model & $\mathbf{R}$ & R square & $\begin{array}{c}\text { Adjusted R } \\
\text { squared }\end{array}$ \\
\hline & $\begin{array}{l}\text { Visit Intention } \\
\text { (Y) }\end{array}$ & $\begin{array}{l}\text { (Constant) } \\
\text { Brand Antrophomorpism (X) }\end{array}$ & 0.631 & 0.398 & 0.392 \\
\hline & $\begin{array}{l}\text { Visit Intention } \\
\text { (Y) }\end{array}$ & $\begin{array}{l}\text { (Constant) } \\
\text { Brand Antrophomorpism (X) } \\
\text { Culture Effect (Z) }\end{array}$ & 0.665 & 0.443 & 0.426 \\
\hline
\end{tabular}

Table 5. hypothesis testing

\begin{tabular}{lllll}
\hline Hypothesis & t-stat & t-table & Sig. & Conclusion \\
\hline H1: $\begin{array}{l}\text { Brand anthropomorphism to the Visit } \\
\begin{array}{l}\text { intention } \\
\text { H2: }\end{array}\end{array}$ Culture effect moderates Brand \\
\begin{tabular}{l} 
anthropomorphism and Visit intention \\
\hline
\end{tabular}
\end{tabular}

Source : statistical data (2020)

\subsection{Discussion}

Looking at the descriptive statistical results in Table 5 , it can be seen that the majority of respondents are women and also young, it means that the culture in Indonesia today is that many women and young people are accustomed to staying at hotels. This culture is very different from the past where women rarely dared to travel far and stay in hotels because they carried a negative image. A years ago, people who could stay at hotels were people who were already working and had their own income, because hotels were luxurious places to stay. Todays, technology and other conveniences can shift one's view, including on a brand. This seems to be captured by "RedDoorz". "RedDoorz" uses the concept of Brand Anthropomorphism in influencing consumers to stay.

If you look at the comparison between the t-table value and the t-statistic and also the significance value, it can be assumed that the effect of brand anthropomorphism is very significant on visit intention. Referring to previous studies, it says that apart from brand anthropomorphism, there are still many other factors that influence [16]. [17] says that brand signature, brand awareness, brand attitude, and brand reputation are also influential on visit intentions but the most influential one is brand anthropomorphism. This research is similar with research [18] and [19]. The anthropomorphism theory which states that humans perceive objects (objects) as if they have human-like characteristics and personalities, can be implemented by "RedDoorz" through their social media [13]. Having an Instagram account with quite a number of followers, uploading photos and videos interesting, and the interactive "RedDoorz" concept in social media is able to shape consumers' emotional perceptions. With the concept of brand anthropomorphism, Brand anthropomorphism has a positive effect on visit intention. Referring to these results, the first hypothesis is supported.

The interesting of this research is about psychological factors and the use of technology, it turns out that consumer culture is very influential. This is reflected in the descriptive statistics of respondents in Table 1 that illustrating that young people currently travel out of town during holidays even though with a limited budget and confirmed by the results of statistical tests in Hypothesis 2 which states that the culture effect moderates the influence of brand anthropomorphism on visits intention (Table 4). From the results of the Moderate Regression Analysis test, it is proven that culture moderates the effect of brand anthropomorphism on visit intention as evidenced by the t-statistic is greater than t-table $(8.2>1.65964)$ and a significance 
value $(0.00<0.05)$ so that the hypothesis was supported. It can be interpreted that culture influences the views of one's thoughts on visit intention in "RedDoorz". Along with the increasing penetration of internet users in Indonesia, young people remain the main target for businesspeople including the hotel booking platform "RedDoorz". The concept and features on the "RedDoorz" web that are simple, elegant, and easily accessible are an attraction for new customers or consumers. High ratings and positive testimonials from users clearly displayed on the reddoorz.com web feature shape people's attitudes and interests to visit [4]. The real thing is what makes someone's view to trust "RedDoorz". The development of the information and communication technology is supporting with the increasing use of social media marketing which is able to form a brand anthropomorphism.

\section{Conclusion}

This study aims to examine the effect of brand anthropomorphism on visit intention and the effect of culture effect as a moderating variable between brand anthropomorphism on visit intention. Based on the results that has been done, it can be concluded that brand anthropomorphism has a positive effect on visit intention and the culture effect moderates the effect of brand anthropomorphism on visit intention. The interesting thing from this research is because it turns out that culture greatly influences of person's perspective, especially young people in choosing a place to stay. It proves by statistical score and significance scores. Culture in Indonesia, a person's decisions are also strongly influenced by the opinions of those closest to him. The limitations of this research was conducted at the beginning of the Covid-19 pandemic so that it did not get a sample of respondents evenly throughout Indonesia. Future research is expected to explore more further about the relationship between brand anthropomorphism and culture.

\section{Acknowledgement}

This research was funded by an accelerated research grant from Research, Development and Community Service Division, University of Muhammadiyah Magelang in 2019/2020.

\section{References}

[1] ------. 2020. Hotel yang Bikin Nginep Lebih nyaman https://www.reddoorz.com/blog/id/uncategorized/fasilitas-reddoorz-hotel.

[2] Aditya, N.R. (2020). "Trend Wisata Milenial Indonesia". Kompas.com. https://travel.kompas.com/read/2020/01/16/061800327/5-fakta-tren-wisata-generasi-milenialindonesia-pada-2019?page $=$ all

[3] Ardyan, E., Farida, N., \& Retnawati, B. B. (2018). E-WOM attractiveness, e-brand community trust, e-brand community experience and brand loyalty: A study on XIAOMI electronic brand community in Indonesia. Journal of Business and Retail Management Research Vol. 12 Issue 3, 231-240.

[4] Lee, S. A., \& Oh, H. (2019). Anthropomorphism and its implications for advertising hotel brands. Journal of Business Research. 
[5] Ketron, S., \& Naletelich, K. (2019). Victim or beggar? Anthropomorphic messengers and the savior effect in consumer sustainability behavior. Journal of Business Research Volume 96, 73-84.

[6] Waytz, A., Cacioppo, J., \& Epley, N. (2010). Who Sees Human? The Stability and Importance of Individual Differences in Anthropomorphism. Perspectives on Psychological Science 5(3) , 219232.

[7] Hollebeek, L. D., Glynn, M. S., \& Brodie, R. J. (2014). Consumer Brand Engagement in Social Media: Conceptualization, Scale Development and Validation. Journal of Interactive Marketing 28, 149-165.

[8] Phang, C. W., Zhang, C., \& Sutanto, J. (2013). The influence of user interaction and participation in social media on the consumption intention of niche products. Information and Management Vol. 50, No. 8, 661-672.

[9] Kolbl, Ž., Arslanagic-Kalajdzic, M., \& Adamantios, D. (2019). Stereotyping global brands: Is warmth more important than competence? Journal of Business Research 104, 614-621.

[10] Epley , N., Waytz, A., \& Cacioppo, J. T. (2007). On seeing human: A three-factor theory of anthropomorphism. Psychological Review, 864-886.

[11] Wang, L., Li, H., Zhao, C., Li, S., Kong, L., Wu, W., . . Zhang , H. (2017). The inhibition of protein translation mediated by AtGCN1 is essential for cold tolerance in Arabidopsis thaliana. lant Cell Environ 40(1), 56-68.

[12] MacInnis, D. J., \& Folkes, V. S. (2017). Humanizing brands: When brands seem to be like me, part of me, and in a relationship with me. Journal of Consumer Psychology, 355-374.

[13] Guido, G., \& Peluso, A. M. (2015). Brand anthropomorphism: Conceptualization, measurement, and impact on brand personality and loyalty. Journal of Brand Management Vol. 22, 1-19.

[14] Trejos \& Wang. (2020). Curcular economy and comsumer acceptance: An exploratory study in East and Asia. Journal of Cleaner Production Volume 247.

[15] Dimofte, C., Ronkainen, I. A., \& Johansson, J. (2008). Cognitive and Affective Reactions of US Consumer to Global Brands. Journal of International Marketing, 343-371.

[16] Su, N., \& Reynolds, D. (2017). Effects of brand personality dimensions on consumers' perceivedself-image congruity and functional congruity with hotel brands. International Journal of Hospitality Management 66, 1-12.

[17] Foroudi, P. (2018). Influence of brand signature, brand awareness, brand attitude, brand reputation on hotel industry's brand performance. International Journal of Hospitality Management.

[18] Grzesiak, M. (2015). E-BRANDING vs. TRADITIONAL BRANDING. MODERN MANAGEMENT REVIEW, 89-100.

[19] Mohammed, A., \& Rashid, B. (2018). A conceptual model of corporate social responsibility dimensions, brand image, and customer satisfaction in Malaysian hotel industry. Kasetsart Journal of Social Sciences 39, 358-364. 